POLSKA AKADEMIA UMIEJĘTNOŚCI

Tom XIV

PRACE KOMISII HISTORII NAUKI PAU

2015

Andreas KLEINERT

Martin-Luther-Universität Halle-Wittenberg, Institut für Physik

kleinert@physik.uni-halle.de

\title{
LEONHARDI EULERI OPERA OMNIA: EDITING THE WORKS AND CORRESPONDENCE OF LEONHARD EULER ${ }^{1}$
}

\begin{abstract}
The paper gives an overview on the history and present state of the edition of the complete works of Leonhard Euler (1707-1783). After several failed initiatives in the 19th century, the project began in 1907 with the edition of Euler's printed works. The works were divided into three series: I. Mathematics (29 volumes); II. Mechanics and Astronomy (31 volumes); and III. Physics and Miscellaneous (12 volumes). After several ups and downs due to two World Wars and economic problems, the publication of the printed works with a total of 72 volumes is nearly finished. Only two volumes on perturbation theory in astronomy are still missing.

The publication of series IV (manuscripts and correspondence) started in 1967 as a joint project of the Swiss and the Soviet academies of sciences. The manuscript edition was postponed, and the project focussed on Euler's correspondence which contains approximately 3000 letters, 1000 of them written by Euler. The correspondents include famous mathematicians of the 18th century like d'Alembert, Clairaut and the Bernoullis, but also many less-known people with whom Euler corresponded on a great variety of subjects.

A major problem is to find and to finance appropriate editors who are able to read French, Latin, and the old German handwriting, and who are acquainted with history, culture and science of the 18th century. During the last 50 years, the editors gathered copies or scans of most of the preserved Euler's letters. The original letters addressed to Euler were made available to the editorial group in Switzerland by the Russian Academy of Sciences before World War I, and before their restitution in 1947 the editors made fairly good photographs that are now an important part of the material basis of the edition.

1 This paper is a revised and enlarged version of Kleinert and Mattmüller 2007. Previous and partly outdated descriptions of the Euler project are Engelsman 1990 and Fellmann and Im Hof 1993.
\end{abstract}


Each volume of the letter series (VIA) contains Euler's correspondence with one or more of his contemporaries, presented in a chronological order. Up to the present day, four volumes of the correspondence have been published, in addition to an inventory of all known letters to and from Euler, including short summaries and useful information about the date, language and location of the existing copies, and former publication. Four more volumes are in progress and will be published in 2016 or 2017. The remaining letters that are not intended for publication in the printed volumes are planned to be made available in an online edition.

Keywords: Leonhard Euler, complete works, correspondence, editing policy

\section{Introduction}

The edition of the works of Leonhard Euler, entitled Leonhardi Euleri Opera omnia, is a monument of scholarship known to most historians of science and certainly to every historian of mathematics. This is the dust cover of the most recent volume, published in 2015.

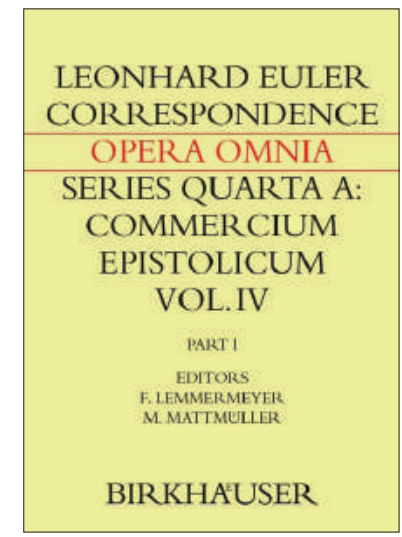

Fig. 1. Dust cover of volume IVA/4, part 1 (Basel 2015)

\section{Remarks on Euler's biography ${ }^{2}$}

Leonhard Euler was born in Basel on April 15th, 1707, as the son of a protestant minister. He studied mathematics with Johann I Bernoulli at Basel University. In 1727, Euler followed an invitation to the newly organized St. Petersburg Academy of Sciences. He never returned to Switzerland, not even for a visit. In 1741 he moved to Berlin where he became director of the class of mathematics of the Prussian Academy. 25 years later, in 1766, he returned to St. Petersburg as a full member of the Russian Academy of Sciences. He held this position until his death on September 18th, 1783.

\footnotetext{
${ }^{2}$ Concerning Euler's biography, cf. Fellmann 2007.
} 


\section{Euler's writings}

During his lifetime, Euler published about 560 writings; most of them were articles scattered in various periodicals and collective volumes. Shortly before he died, he predicted that it would take at least twenty years for the Petersburg Academy to publish all the manuscripts he would leave behind. ${ }^{3}$ It turned out that this prediction was too optimistic: only in 1830 was the stock of unpublished Euler manuscripts exhausted. Until that year the number of Euler's publications had increased to 756.

In 1844, Euler's great-grandson Paul-Heinrich Fuss found another 61 manuscripts, which his brother Niklaus Fuss published in $1862 . .^{4}$ In the early twentieth century, the Swedish mathematician Gustav Eneström compiled the standard inventory of Euler's writings. This inventory, which is generally referred to as the Eneström Index, was published between 1910 and 1913. ${ }^{5}$ The 866 publications listed by Eneström include a certain amount of correspondence published in the 19th and early 20th century that was actually not Euler's printed publications. When we omit this correspondence, the number of Euler's printed publications amounts to about 850 .

After the publication of the Eneström Index, only few more printed publications by Euler have been identified - including an anonymously published paper that had escaped the attention of the Swedish mathematician and that could be identified on the basis of the correspondence. ${ }^{6}$

\section{Prehistory: Euler's editions of the 19th century ${ }^{7}$}

The first attempts to publish Euler's complete works go back to the 1830s. Two such initiatives were launched simultaneously. One of them was started by Euler's great-grandson Fuss, who was the permanent secretary of the Petersburg Academy. Although Fuss was encouraged by many prominent mathematicians and strongly supported by Carl Gustav Jacobi, the project was finally abandoned when it turned out that it would exceed the financial capacities of the Academy's budget. The only result of Fuss's and Jacobi's initiative was the publication, in 1849, of two volumes of Commentationes arithmeticae (Papers on Arithmetic) which included 94 articles that had already been published, and five unpublished manuscripts.

At the same time (1830s), a group of Belgian mathematicians was undertaking an identical project. They were more fortunate than the Russians in so far as five volumes of this edition came out of press. This edition was sharply criticized because of its bad quality. ${ }^{8}$

\footnotetext{
${ }^{3}$ Cf. Bernoulli 1780, p. 13.

${ }^{4}$ Euler 1862.

${ }^{5}$ Eneström 1910-1913.

${ }^{6}$ De causa gravitatis, cf. section 12.

7 To this section cf. Biermann 1983.

8 Cf. Bosmans 1909.
} 
These early editors of Euler's works had one thing in common: their intention was to make Euler's works accessible to contemporary scientists, and in particular to mathematicians. The editors believed that Euler's writings would still stimulate mathematical research, and that mathematicians should study his works with unbroken intensity, according to the famous words of Laplace "Read Euler, read Euler, he is the master of us all." This was also the reason for the Jesuit Johann Georg Hagen to publish a new, but still incomplete bibliography of Euler's writings in $1896 .^{10}$

At the beginning of the 20th century, the Russian Academy of Science launched a new initiative for the publication of Euler's complete works. In consideration of the failure of all previous attempts, the Russians looked for allies with whom they could share the work and the expenses, and an evident ally with regard to Euler was of course the Prussian Academy of Science in Berlin, where Euler had served for 25 years. Initially, the Berlin academicians were quite enthusiastic about this plan, but when it turned out that the Russians wanted to divide the task so that they would publish the mathematical works, whereas the publication of the physical writings would be left to the Germans, the Berlin Academy asked the most distinguished physicist among its members for his advice. This was Max Planck, and in a famous statement Planck argued that the publication of Euler's physical writings was "not in the interest of physics as a science of our time". ${ }^{11}$ As a result of this statement, the Prussian Academy declined to participate in funding the project. Since the whole enterprise was too expensive for the Russian Academy, this initiative also ended with a failure.

\section{The printed works (series I-III)}

In 1907, Ferdinand Rudio, a professor of mathematics at the Zürich Polytechnic (now Swiss Federal Institute of Technology), started an initiative that ultimately turned out to be successful. On the occasion of the commemoration of Euler's 200th birthday in the city of Basel, Rudio delivered a thrilling speech in which he appealed to Swiss patriotism and international solidarity in favor of an edition of Euler's complete works. He addressed his words in particular to the members of the Swiss Society for Natural Science (SCNAT) (Schweizerische Naturforschende Gesellschaft (SNG), now Swiss Academy of Science), and to the representatives of the Academies of Berlin and Saint Petersburg, who attended the ceremony.

Rudio's speech culminated in the words:

Switzerland will always be grateful to the academies of Berlin and Saint Petersburg for having given our Euler, to whom his native country was too small, the opportunity to perform his outstanding work. ${ }^{12}$

9 The quote is reported in Libri 1846, p. 51.

${ }^{10}$ Hagen 1896.

11 Biermann 1963, p. 239.

12 "Die Schweiz wird der Petersburger und der Berliner Akademie stets das Gefühl der Dankbarkeit bewahren, dass sie unserm Euler, für den das eigene Vaterland zu klein war, ein 
These were the right words on the right occasion. The SNG decided that the edition of Euler's work was a duty of honor (Ehrenpflicht) for its members, and appointed a committee (Euler-Kommission) that was in charge of executing the project. ${ }^{13}$

The first step that was taken by the Euler committee was a fundraising effort. So-called Zeichnungsscheine (declarations of donation) were sent to public institutions, enterprises, business companies and individuals. The addressees of these Zeichnunsgscheine were requested to indicate the amount of their possible donation, and it was said that it depended upon the total amount of money that would be promised by the donors, whether the society would eventually start with the project or not.

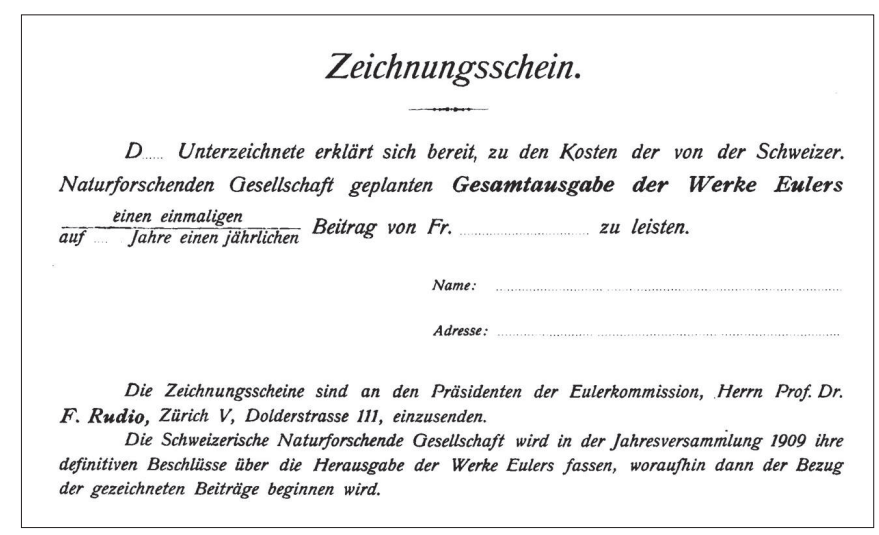

Fig. 2. Declaration of donation (Zeichnungsschein)

The response to this fundraising campaign was fantastic. 100,000 Swiss francs were offered by donators in Switzerland, 30,000 francs by donators of other countries. In Romania, money was even collected from school children in the gymnasia. ${ }^{14}$ A great number of individuals subscribed to the edition in advance, and each of the three Academies of Berlin, Paris and Saint-Petersburg signed a subscription for 40 copies. The amount of money coming from subscriptions was nearly three times as much as the donations, i.e. about 300,000 francs. With a total of nearly half a million francs, a medium-term financing was guaranteed.

Money alone is not the only precondition for realizing such a project. What is also needed are qualified people who are able and willing to do the work. In this respect, the Euler committee was equally successful.

Twenty mathematicians of international reputation spontaneously agreed to serve as editors of one or more volumes, including Jacques Hadamard from Paris, Gustaf Eneström

grösseres geboten und ihm die Möglichkeit bereitet haben, in ungetrübter Schaffensfreudigkeit sein grosses Lebenswerk zu vollenden“ (Rudio and Schröter 1907, p. 541).

13 Rudio and Schröter 1907, p. 543.

14 Rudio 1911, p. XXVIII. 
from Stockholm, Tullio Levi-Civita from Padova, Gerhard Kowalewski from Prague and Heinrich Weber from Strasbourg, the editor of the first volume, published in 1911.

When the edition started, the committee optimistically promised that a single volume would not cost more than 25 francs, that the total number of volumes would be about 40 , and that the edition would come to an end within 12 years. ${ }^{15} \mathrm{~A}$ few years later, after the publication of the Eneström Index, it turned out that the Euler committee had considerably underestimated the size of Euler's written legacy. In 1913, the estimated number of volumes was increased to 66. Within the following years, the number of volumes for Euler's printed works was raised to 72 - that is where we are now.

The edition of Euler's printed works is divided into three series:

I. Mathematics (29 volumes)

II. Mechanics and Astronomy (31 volumes)

III. Physics and Miscellaneous (12 volumes)

In a paper of 16 printed pages, the committee defined the guidelines and requirements that should be followed by the different editors. ${ }^{16}$ I will just mention some important points:

1. The edition will include the works of Euler's son, Johann Albrecht, as far as they have been suggested or revised by Leonhard Euler. This principle has been followed up to the present day; the last volume of series III (No. 10), published in 2004, includes eleven papers by the father and four by the son.

2. Every text will be reprinted in its original language, including archaic spelling. Only evident printing errors will be silently corrected.

3. A somewhat curious rule was established for the footnotes: they should be written in the same language as Euler's text, which implies that Latin texts have to be commented in Latin.

The first volume was published in 1911; it was Euler's Vollständige Einleitung zur Algebra. Until the outbreak of World War I, 12 volumes had been published. The distribution of the following volumes over the years is shown in fig. 3 .

Leonhardi Euleri opera omnia, Series I-III

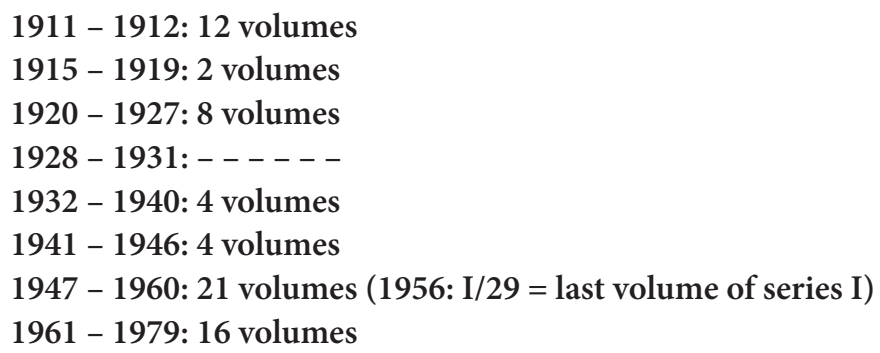

15 Rudio and Schröter 1909, p. 475; p. 479.

${ }^{16}$ A copy of this Redaktionsplan für die Eulerausgabe, signed by Adolf Krazer and Paul Stäckel, is preserved in the Bernoulli-Euler-Zentrum, University Library of Basel. 


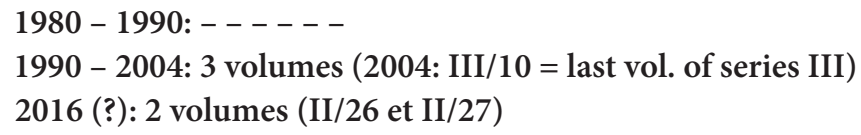

Fig. 3. The publication of Euler's printed works (series I-III) from 1911 to the present

Many ups and downs accompanied the history of the edition in the 20th century. The continuous publication of the Euler volumes was slowed down by the effect of two World Wars and by the necessity to find new publishers for political and financial reasons. Until 1935, the Euler volumes were published by the prestigous scientific publisher Teubner (Leipzig). From 1935 to 1950 Teubner was joined by Orell Füssli (Zürich). As the cooperation with a publisher in the German Democratic Republic grew more and more difficult, the publication was entrusted exclusively to Orell Füssli between 1952 and 1974. Since 1975, the Euler volumes are published by Birkhäuser (Basel), which became Springer (Basel) in 2014.

A real disaster occurred in 1931: the private bank Christ-Paravicini, where the Euler committee had deposited its funds, went bankrupt and the Euler committee lost 80,000 francs.

However, there were not only political and economic obstacles. In the second half of the 20th century, it became more and more difficult to find qualified editors. Mathematicians who were able to read Latin texts were a kind of disappearing species, and for the volumes that were published after 1960, mathematicians and physicists had to be replaced as editors by professional historians of science.

The consequence of this shift was a quite different philosophy of editing. For the founders of the Euler edition and for the first generation of editors, the main purpose of the edition had been making the original texts widely available with commentaries restricted to a minimum. In a paragraph of the editorial outline of 1910, it was clearly said that the annotations should not degenerate into long historical treatises. This sound principle was increasingly abandoned when historians of science replaced scientists as editors. Some of them used this occasion as an opportunity for presenting all their knowledge and erudition, and there is even a volume of more than 400 pages that does not include a single line by Euler. It is just an historical treatise on the history of elastic bodies between 1639 and $1788 .{ }^{17}$ Generally speaking, it can be said that the more recent volumes are characterized by deeper introductions and more extensive footnotes and commentaries.

Along with the arrival of a new generation of editors, the edition began to focus on a different target group of readers. Since the majority of modern scientists is no longer able to read texts written in Latin, German and French, an edition that makes Euler's works available to scientists worldwide would need an additional English translation, which is indeed realized with the last published volume, which was considered to be of special interest for modern mathematicians working on number theory. ${ }^{18}$ While the importance

\footnotetext{
17 Volume II/11.2 (1960), by Clifford Truesdell.

18 Volume IVA/4 (correspondence Euler-Goldbach).
} 
of the edition for mathematicians diminished, it became an extremely valuable tool for historians interested in science and its social and political context in 18th century Europe. as a result, historians, and in particular professional historians of science, have taken over the place of mathematicians, both as readers and in the function of editors.

Now (in 2015), the edition of Euler's printed works is nearly finished. The two missing volumes of series II (II/26 and II/27) will include Euler's papers on perturbation theory in astronomy. We are optimistic that these volumes will be published in 2016 and 2017.

\section{The correspondence and manuscripts (series IVA and IVb)}

Euler's extant correspondence contains approximately 3100 letters exchanged with nearly 300 correspondents; about 1000 letters are by Euler. Most of the letters are from the time when Euler lived in Berlin (1741-1766). The languages of the letters are German, French, and Latin; only a few letters are in Russian. Among the correspondents with whom Euler exchanged more than 100 letters, we find (the numbers in parentheses are the extant letters written by/addressed to Euler): Daniel Bernoulli (19/81), Christian Goldbach (102/94), Pierre Louis Moreau de Maupertuis (124/5), Gerhard Friedrich Müller (111/101), Johann Daniel Schumacher (176/131) and Johann Andreas Segner (0/159). Only three of these are of interest to historians of mathematics because of their mathematical or scientific content: Bernoulli, Goldbach, and Segner. The remaining three letters and a lot of other correspondence of smaller size deal with academy business matters. Schumacher and Müller were officials of the Petersburg Academy and Maupertuis was the president of the Prussian academy.

Already in the first plan of 1910, it was mentioned that Euler's scientific correspondence should be included in the publication of Euler's Opera omnia. But priority was given to the publication of Euler's printed works.

The first 20th-century initiatives to publish parts of Euler's correspondence were independent from the Euler project of the Swiss Academy. They were by no means related to the Opera omnia edition, but were the result of a cooperation between the Academy of Science of the Soviet Union and the Academy of Science of the German Democratic Republic, which considered itself the legal successor of the Prussian Academy. On the occasion of Euler's 250th anniversary, the two academies decided to publish all the Euler letters that were related to their cooperation in the 18th century. The resulting three volumes, with more than 600 letters, were published by Adolf P. Juškevič and Eduard Winter between 1959 and 1976 under the title Die Berliner und die Petersburger Akademie der Wissenschaften im Briefwechsel Leonhard Eulers. ${ }^{19}$

In 1965, the same editors republished the correspondence between Euler and Christian Goldbach, ${ }^{20}$ which had already been printed by Paul-Heinrich Fuss in the 19th centu-

\footnotetext{
19 Juškevic and Winter 1959-1976.

20 Juškevic and Winter 1965.
} 
ry. ${ }^{21}$ Furthermore, the Soviet Academy of Sciences published two more volumes of Euler's correspondence ${ }^{22}$ and an inventory with summaries of all Euler's letters preserved in its Leningrad Archive. ${ }^{23}$

Encouraged by these Soviet and East German activities, the Swiss Euler Committee finally decided in 1967 to start an additional series of the Opera Omnia, which was to contain Euler's correspondence and unpublished manuscripts. It was planned that this series IV should be divided into two sub-series: IVA for the correspondence and IVB for the manuscripts. The first decision of the newly-created editorial board of series IV was to postpone the publication of the manuscript series and to focus on the correspondence. The correspondence series was planned as a joint project of the Swiss and the Soviet Academies, and its first editorial committee was composed of four members from the USSR and four from Switzerland. This committee, which was to be exclusively responsible for Series IVA, was chaired by Walter Habicht until 1985. Habicht was followed by Emil Fellmann, who was also the director of the Euler Archive in Basel. In 2006, the author of this article succeeded Fellmann as the general editor of series IVA.

The following guidelines were set up for the publication of Euler's correspondence:

1. The correspondence is not published in a general chronological order; instead every volume will include an exchange of letters with one or more correspondents.

2. Earlier decisions, in particular concerning the scientific or non-scientific character of the letters, were revised; it was decided that all the letters to and from a certain correspondent will be edited if the correspondence is published.

3. For each volume, a "working language" is determined for the introduction, footnotes and commentaries. As a general rule, this will be the language of the majority of the letters in the respective volume. German was consequently chosen as the working language for volumes 2, 3 and 8 and French for volumes 5, 6 and 7. For volume 9, which contains mostly letters written in Latin, the working language will be Italian, which is the native language of the editor Antonio Moretto.

4. The text of the letters will be published completely (including the civilities at the beginning and at the end, which were often omitted in former editions) and in the original language. Only letters in Latin will additionally be translated into the working language of the volume.

Two exceptions were made for volumes IVA/3 and IVA/4. In volume IVA/3, the letters exchanged between Euler and Daniel Bernoulli, written in a strange mixture of German, French, and Latin, will be translated into modern German, in addition to the original text. As for the Euler-Goldbach correspondence (vol IVA/4), the editorial board was convinced that these letters include so many ideas and suggestions that are of interest for modern mathematicians (in particular regarding number theory) that they ought to be accessible to a worldwide community of scientists and not only to historians of science.

\footnotetext{
${ }^{21}$ Fuss 1843.

22 Кладо et al. 1963; Grigorian and Youschkevitch 1968.

23 Юшкевич and Смирнов 1967.
} 
Hence, it was decided to choose English as the working language for this volume and to translate all the letters into English, in addition to the original text, which is either Latin or a mix of German, Latin and French.

This is an overview of the published and forthcoming volumes of the series IVA. The working language is given in parentheses:

\section{Series quarta A: Commercium epistolicum \\ (Correspondence: 9 volumes in 11 parts)}

1. Descriptio commercii epistolici. Beschreibung, Zusammenfassungen der Briefe und Verzeichnisse. Edited by Adolf P. Juškevič, Vladimir I. Smirnov and Walter Habicht (German). 1975.

2. Briefwechsel von Leonhard Euler mit Johann I Bernoulli und Niklaus I Bernoulli. Edited by Emil A. Fellmann and Gleb K. Mikhajlov (German). 1998.

3. Briefwechsel von Leonhard Euler mit Daniel Bernoulli, 2 parts (German). Planned for 2016.

4. Correspondence of Leonhard Euler with Christian Goldbach. 1st part: Introduction, original texts. 2nd part: Translations, indices. Edited by Franz Lemmermeyer and Martin Mattmüller (English). 2015.

5. Correspondance de Leonhard Euler avec A. C. Clairaut, J. d'Alembert et J. L. Lagrange. Edited by Adolf P. Juškevič and René Taton (French). 1980.

6. Correspondance de Leonhard Euler avec P.-L. M. de Maupertuis et Frédéric II. Edited by Pierre Costabel, Eduard Winter, Ašot T. Grigorijan and Adolf P. Juškevič (French). 1986.

7. Correspondance de Leonhard Euler avec L. Bertrand, Ch. Bonnet, M.M. Bousquet, J. de Castillon, G. Cramer, Ph. Cramer, G. Cuenz, G. L. Lesage, J. M. von Loen, J. C. Wettstein (French). In preparation.

8. Briefwechsel von Leonhard Euler mit T. Abbt, B. Brauser, J. P. Eberhard, A. von Haller, F. C. Jetze, W. J. G. Karsten, C. A. Körber, C. G. Kratzenstein, J. G. Krüger, J. J. Lange, J. A. Osiander, J. E. Philippi, J.H. Schulze, J.A. von Segner und J.W. von Segner (German). In preparation.

9. Carteggio di Leonhard Euler con M. Knutzen. Edited by Antonio Moretto (Italian). In preparation.

The first volume of series IVA was published in 1975. It is an inventory of all the letters to and from Euler known at that time. For each letter, it gives a short summary and information about the date, the language, the existing copies, the place where the original is located and whether it has already been published.

Five years later, the first "proper" correspondence volume appeared: volume IVA/5 includes Euler's correspondence with Clairaut, d'Alembert and Lagrange, edited by René Taton and A.P. Juškevič. In 1986, Pierre Costabel, Eduard Winter, A.T. Grigorjan and A. P. Juškevič published Euler's correspondence with Maupertuis and Frederick II (volume IVA/6) and in 1998 volume IVA/2 presented Euler's correspondence with Johann I and Niklaus I Bernoulli, edited by Emil Fellmann and Gleb K. Mikhajlov. 
Due to problems with funding and the recruitment of qualified editors, no further volume of series IVA was published between 1998 and 2015, the year of publication of volume IVA/4.

\section{The material basis of the correspondence edition}

Since the beginnings of the Euler Edition, the Euler Archive in Basel, which is now part of the Bernoulli-Euler-Zentrum located in the Basel University Library, has gathered copies of the extant Euler letters spread in libraries, archives, and private collections all over the world. As for the letters addressed to Euler, they are mostly preserved in the archive of the St. Petersburg Branch of the Archive of the Russian Academy of Sciences (SPbB ARAS). In the 19th century, a small part of the Euler correspondence was transferred to the manuscript department of the University Library of Tartu (Estonia); all these letters to and from Euler are now accessible online. ${ }^{24}$

When the project started in 1907, the cooperation between the Swiss Euler Committee and the Russian Academy was excellent, and before World War I, the complete collection of Euler papers was transferred to Switzerland as a deposit, in order to promote the edition of Euler's works. ${ }^{25}$ Only at the end of the 1930s, the Soviet Academy of Sciences claimed them back, but due to political difficulties (Switzerland had no diplomatic relations with the Soviet Union before 1946), the negotiations lasted until the outbreak of World War II, and again it was impossible to bring the Euler papers back to Russia. Only in 1947, they were finally restituted to their legal owners and transferred to Leningrad.

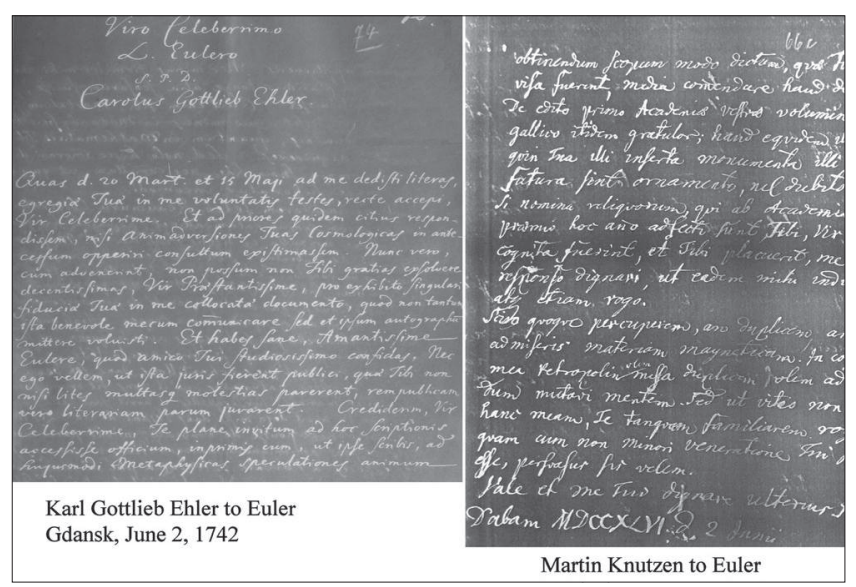

Fig. 4. Photographs of letters to Euler, preserved in the Bernoulli-Euler-Zentrum in Basel

24 DSpace Repository at University of Tartu 2002-2015.

25 An inventory of Euler's letters and manuscripts is given in Eneström 1913, pp. 197-205. 
As long as the Euler papers were in Switzerland, the Euler committee was allowed by the Petersburg archive to make copies (photographs) of all the documents, including Euler's correspondence. These photos are the basic material of the editorial work done in Basel. They are of fairly good quality. Only sometimes did the photographer omit a page of a letter or the camera was held in a bad positon, so that parts of the margin are missing. In such exceptional cases, the Petersburg archive provided scans of high resolution.

\section{Recruiting and financing qualified editors}

Since its beginnings the edition has never been sufficiently funded. The funds gathered at the beginning of the 20th century, coming from the occasional donations, the revenue from the sales of the printed volumes and from the contributions of the Leonhard Euler-Gesellschaft, a society of mainly private supporters of the edition, were not intended for salaries. Their purpose was to cover the printing costs and the expenses connected with the gathering of the material: travels to archives, microfilms, photocopies, scans, and renting the rooms where the Euler Archive was located in Basel until 2012. But nobody was ever paid for the work they were doing as editors. The editors of series I-III were mostly mathematicians who had stable positions as researchers or university professors and who considered it a great honor to contribute to the prestigious Euler Edition.

The correspondence series was conceived according to the same system: university professors who were more than 60 years old and who were financially independent were asked to serve as unpaid editors.

But even among professors of mathematics, physics or other scientific disciplines, it became more and more difficult to find fully qualified editors. There are simply not so many people around who possess the special skills required for this work. The ideal editor should be familiar with the mathematics, physics and/or astronomy of the 18th century, have a solid knowledge of Latin, French and German and be able to read 18th-century German handwriting, which is often a challenge in itself.

It turned out that most of the editors (including the author of the present paper) and collaborators of the correspondence volumes were indeed retired professors. Many of them began cooperating with the Euler Committee shortly before their retirement, hoping that they would soon be free from other obligations and able to concentrate on this work. In principle, this is a good concept, because such people have long experience with such matters and are financially independent. The major disadvantage of this principle, however, is that the Euler Committee has virtually no leverage in motivating them to finish their work within a reasonable amount of time, and regrettably many of them passed away before the work was done (cf. fig. 5).

A typical example is illustrated by the history of volume IVA/7, which was delayed by a long series of misfortunes. More than 25 years ago, I was asked by the editors Adolf P. Juškevič and René Taton to take care of the nine letters of Euler's correspondence with the Geneva physicist Georges-Louis Lesage. I submitted the manuscript in 1992. At that time, Pierre Speziali, a retired mathematician and historian of mathematics at the 
University of Geneva, was working on the correspondence with Gabriel and Philibert Cramer. In 1993 Juškevič died, and at the request of René Taton, I was named co-editor of the whole volume. Speziali died in 1995 and Taton, who was taking care of several items of correspondence of that volume, passed away in 2005, not to mention other deceased collaborators like Mirko Grmek, Roselyne Rey and Pierre Costabel, who all left piles of unfinished manuscripts behind.

\begin{tabular}{|l|l|}
\hline Pierre Costabel & $\dagger 1989$ \\
\hline Adolf P. Juškevič & $\dagger 1993$ \\
\hline Pierre Speziali & $\dagger 1995$ \\
\hline Roselyne Rey & $\dagger 1995$ \\
\hline Mirko Grmek & $\dagger 2000$ \\
\hline René Taton & $\dagger 2005$ \\
\hline Judith Kopelevič & $\dagger 2009$ \\
\hline Emil A. Fellmann & $\dagger 2012$ \\
\hline
\end{tabular}

Fig. 5. Former collaborators of the correspondence series.

The Euler Committee finally decided to charge two young scholars, a PhD student and a postdoc, with the task on the basis of limited half-time paid positions in Basel. Finding qualified candidates and acquiring the money for paying them was, however, not an easy endeavour. But the work is going on, and the publication for this volume is planned for 2017 .

\section{Volume IVA/9: The Euler-Knutzen correspondence}

A fortunate coincidence enabled the Euler Committee to include into series IVA correspondence of particular interest for the history of philosophy. Antonio Moretto, professor emeritus of philosophy at the university of Verona, accepted to serve as editor of Euler's correspondence with the Königsberg professor Martin Knutzen (1713-1751). Knutzen died at a young age, and apart from his publications we have very few original sources or documents about him. However, as a professor of philosophy at the University of Königsberg, Knutzen was one of the most influential academic teachers of Immanuel Kant and, as far as we know, it was through Knutzen that Kant became familiar with Newtonian physics and with the philosophy of Leibniz. The topics of his letters to Euler include physics, astronomy, philosophy and also details about Knutzen's private life and various events at the university of Königsberg. The correspondence consists of 72 letters from Knutzen and two letters from Euler.

\section{Perspectives for the future}

The Swiss National Science Foundation will no longer finance classical printed editons. So the edition of Series IVA will stop with the publication of the volumes listed above. There will definitely be no complete printed edition of the total Euler correspondence. 
This is very regrettable in view of the vast amount of letters which are still unpublished and which include real treasures. Here are some examples of Euler's correspondence that will not be included in series IVA.

\begin{tabular}{|l|c|c|}
\hline \multicolumn{1}{|c|}{ Name } & $\begin{array}{c}\text { Total number } \\
\text { of letters of the } \\
\text { correspondence }\end{array}$ & $\begin{array}{c}\text { Number of letters } \\
\text { from Euler }\end{array}$ \\
\hline Jean de Condorcet (Paris, mathematics) & 6 & 2 \\
\hline Joseph Jérôme de Lalande (Paris, astronomy) & 15 & 4 \\
\hline $\begin{array}{l}\text { Giovanni Jacopo Marinoni } \\
\text { (Vienna, astronomy ) }\end{array}$ & 22 & 10 \\
\hline $\begin{array}{l}\text { Giovanni Poleni } \\
\text { (Prof. university of Padova, mathematics) }\end{array}$ & 25 & 6 \\
\hline Karl Gottlieb Ehler (Gdansk, mathematics) & 20 & 2 \\
\hline Heinrich Kühn (Gdansk, mathematics) & 24 & 4 \\
\hline
\end{tabular}

Our plan is to continue the publication of Euler's correspondence as an online edition in open access, following such examples as the Bernoulli project in Basel $^{26}$ and the Swedish Linné project. ${ }^{27}$ In the best case, we would like to make all the material available online, including the original manuscripts, transcriptions and commentaries. But this can only be realized in cooperation with the Petersburg archive that owns most of the original documents.

\section{Two Euler correspondents related to the history of science in Poland ${ }^{28}$}

Among Euler's correspondents listed above, whose letters will not be included in the series IVA, we find two mathematicians connected to the history of science in Poland: Carl Gottlieb Ehler (1685-1753) and Heinrich Kühn (1690-1769). Both were mathematicians in Gdansk; Ehler was mayor of Gdansk from 1740 to 1753, and Kühn was professor at the Akademisches Gymnasium.

A famous issue in their correspondence with Euler is the problem of the seven bridges of Königsberg (see fig. 6). On March 9th, 1736, Ehler mentioned the problem in a letter to Euler, who had never visited Königsberg, and asked him, also in the name of Kühn, for a solution. He certainly knew that Euler had tackled the problem already a year before, and that he had presented a paper on this topic to the Petersburg Academy

\footnotetext{
${ }^{26}$ Universitätsbibliothek Basel 2015.

27 Linné Project 2003-2015.

${ }_{28}$ On Euler's relations to Poland, cf. Czerniakowska 2006.
} 
on August 26, $1735 .^{29}$ The paper was published in 1741 and is now considered as the foundation of topology and graph theory. ${ }^{30}$

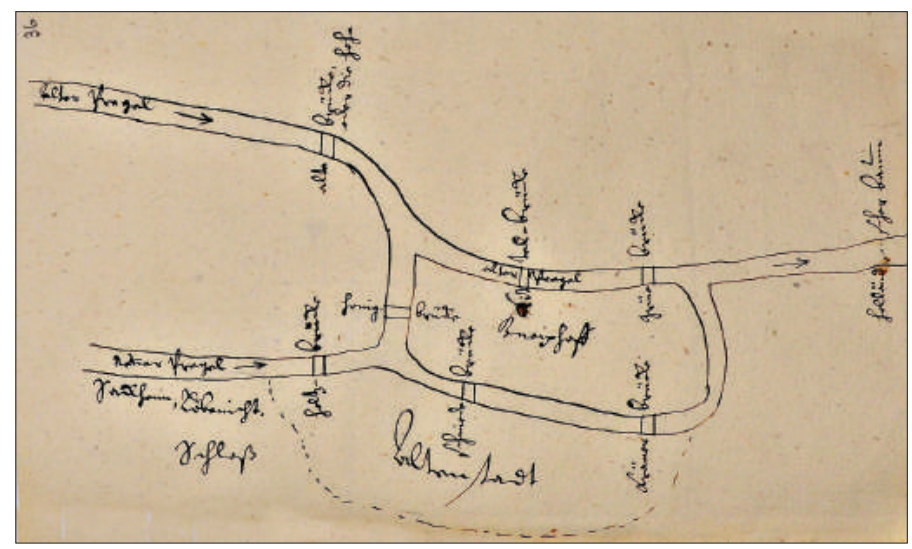

Fig. 6. The problem of the 7 bridges of Königsberg (Euler to Ehler, March 9th, 1736): find a walk through the city that would cross each bridge once and only once.

The starting and ending points of the walk need not be the same.

\section{The significance of the Euler edition for the history of 18th century science}

At the end of this presentation, I will give some examples of the significance of the Euler edition for historical research into the 18th century science. It is in particular the correspondence that provides new insights into the every-day science business of that time. Euler's letters are also a rich source of information on various aspects of Euler's life and work. An exhaustive scientific biography of Euler still does not exist, and it cannot be written as long as Euler's letters are not available.

Volume IVA/8 (Euler's correspondence with Johann Andreas Segner and other members of the university of Halle) will bring to light a vast amount of details about how this university functioned, namely how professors were selected and appointed, how they negotiated their salary, what the intellectual level of the students was, what topics in mathematics and the sciences were presented in the classes, what the significance of experiments in the chemistry and physics lectures was, which instruments were included in the private instrument collection of Christian Wolff and other professors, etc.

Let me give one example that shows how we can learn more about Euler's science from his correspondence. Like many of his contemporaries, Euler was strongly opposed to Newton's theory of gravitation as an action-at-a-distance phenomenon, and he was one of those who desperately searched for a mechanical explanation of attraction and gravity.

\footnotetext{
${ }^{29}$ Eneström 1911-1913, p. 13.

30 Euler 1741.
} 
This was a very controversial issue, because all attempts to find such a mechanical cause of gravitation (in the spirit of Descartes's subtle matter) had failed, and that was probably the reason why Euler in 1743, when he had just arrived in Berlin, published a paper on the theory of gravitation anonymously (fig. 7). ${ }^{31}$

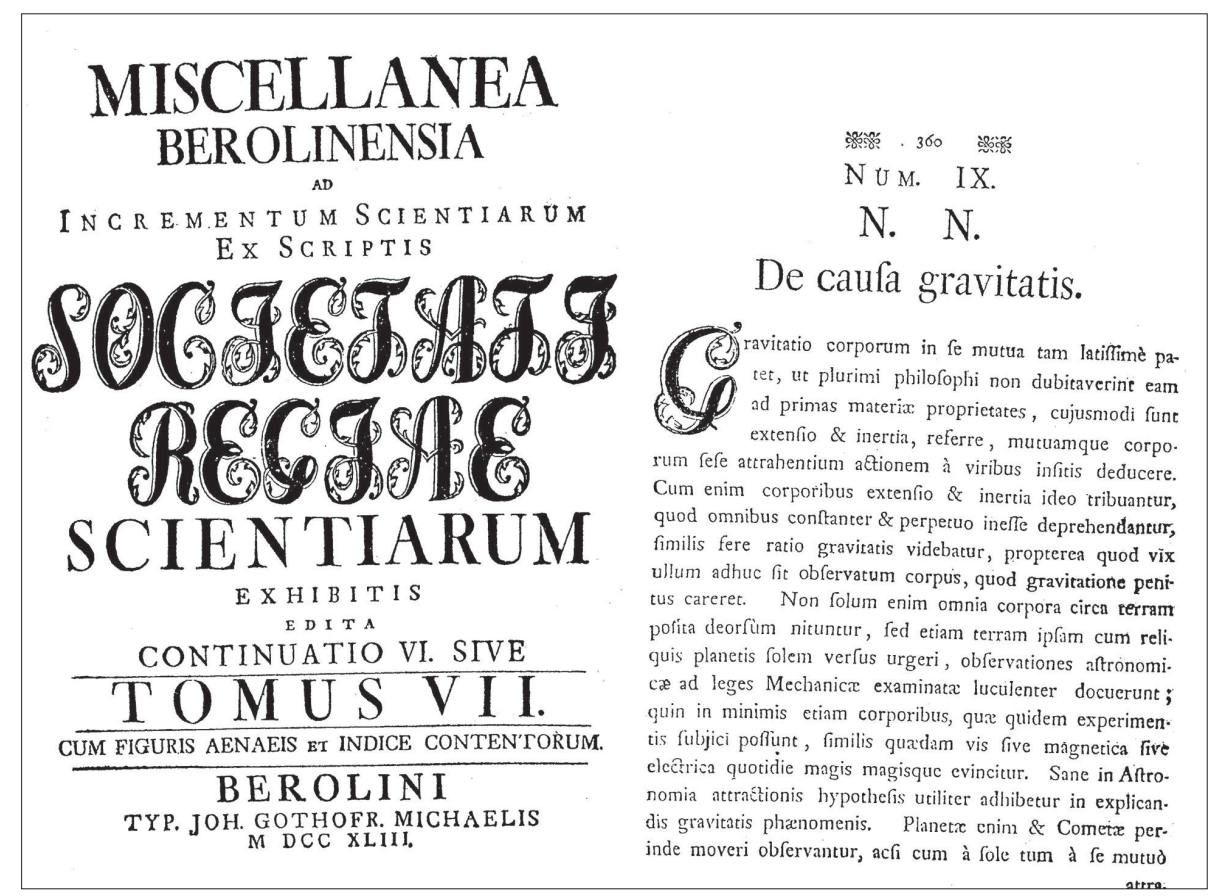

Fig. 7. Euler's anonymous paper on gravitation

Euler later came back to this topic in his Letters to a German Princess ${ }^{32}$, but he was reluctant to publishing his ideas in scientific periodicals or in the proceedings of an academy.

As a result, this article is a key document for anybody who is working on Euler and gravitation theory. ${ }^{33}$

But how do we know that Euler was the author of this paper that is missing in the Eneström Index? We could identify Euler as the author of De causa gravitatis on the basis of his unpublished letters. Volume IVA/7 will include the letters that Euler exchanged with the Geneva physicist Georges-Louis Lesage. Lesage had proposed a kinetic theory of gravity, which offered a mechanical explanation of Newton's force equation. According to Lesage, gravity was caused by the collision of matter, i.e. by a special kind of particles,

${ }^{31}$ Euler 1743.

32 Euler 1768, letter 54-57.

33 On Euler's theory of gravitation, cf. Kleinert 2015. 
which he called particules ultramondaines, because they were originating from beyond our known universe. ${ }^{34}$

With the zeal of a missionary, Lesage tried to persuade the scientists of his time to convert to his theory, and one of the victims that he bombarded with letters was Leonhard Euler. Euler responded politely, but he made clear that he did not share Lesage's view, and that he would explain gravitation in a different manner. In one of the letters (of August 9, 1765), Lesage not only insists on the superiority of his theory, but he also demonstrates a contradiction in Euler's theory of the ether which is, according to Euler, the medium that explains the propagation of light and the effects of gravitation. In this context, Lesage refers to Euler's "Mémoire anonyme imprimé dans le 7e tome des Mélanges de Berlin", i.e. the anonymous paper printed in volume 7 of the Miscelanea Berolinensea. One month later, Euler's response arrived in Geneva. Far from denying that he was the author of the incriminated article, Euler frankly admitted his authorship, and that he had made a mistake:

I agree that you have thoroughly refuted the explication of gravity by which I once hazarded to deduce it from a decrease of the elasticity of the ether in the proximity of matter: and you have convincingly demonstrated that the elasticity of the ether, that I attributed to it as a consequence of the speed of light, would be too small for producing the effect of gravity. ${ }^{35}$

With these lines, Euler clearly outed himself as the author of the gravitation paper of 1743 , and so the editors of the Opera Omnia were provided with a justification for reprinting it in Volume 31 of the 2nd series, published in 1996, as one of the very few papers not listed in the Eneström Index.

\section{BIBLIOGRAPHY}

BERNOULLI Johann

1780: Reisen durch Brandenburg, Pommern, Preussen, Curland, Rußland und Pohlen, in den Jahren 1777 und 1778. Vol. 4. Leipzig: Fritsch.

BIERMANN Kurt-Reinhard

1963: Versuch einer Leonhard-Euler-Ausgabe von 1903/07 und ihre Beurteilung durch Max Planck. Forschungen und Fortschritte, 37, pp. 236-239.

1983: Aus der Vorgeschichte der Euler-Ausgabe 1783-1907. [In:] Leonhard Euler 17071783. Beiträge zu Leben und Werk. Gedenkband des Kantons Basel-Stadt. Basel: Birkhäuser. ISBN 3-7643-1343-9, pp. 489-500.

${ }^{34}$ On Lesage's theory of gravitation, cf. Edwards 2002.

35 "Vous aves solidement refuté l'explication de la gravité, que j’avois hazardée autrefois. [...] Je conviens donc que l'éther ou le milieu dans lequel se fait la propagation de la lumière [...] n'est pas absolument propre à produire la gravité.” Euler to Lesage, September 8th, 1765. 
BOSMANS Henri

1909: Sur une tentative dédition des oeuvres complètes de L. Euler faite à Bruxelles en 1839. Louvain: Ceuterick.

CZERNIAKOWSKA Małgorzata

2006: Leonard Euler (1707-1783) i Polska. Gdansk: Małgorzata Czerniakowska. ISBN 83-924379-2-6.

\section{DSPACE REPOSITORY AT UNIVERSITY OF TARTU}

2002-2015: Epistolae autographae CC Philosophorum cel. II. F 3, Mrg CCCLIVa. Available online: http://dspace.utlib.ee/dspace/handle/10062/4930.

EDWARDS Matthew R.

(ed.) 2002: Pushing Gravity. New Perspectives on Le Sage's Theory of Gravitation. Montreal: Apeiron. ISBN 0-9683689-7-2.

\section{ENESTRÖM Gustaf}

1910-1913: Verzeichnis der Schriften Leonhard Eulers. Leipzig: Teubner (Jahresbericht der Deutschen Mathematiker-Vereinigung, Ergänzungsband 4). [A simplified version of the Eneström Index is available at http://eulerarchive.maa.org/index/enestrom. html.]

1913: Bericht an die Eulerkommission der Schweizerischen naturforschenden Gesellschaft über die Eulerschen Manuskripte der Petersburger Akademie. Jahresbericht der Deutschen Mathematiker-Vereinigung 22, pp. 191-205.

ENGELSMANN Steven Boudewijn

1990: What you should know about Euler's Opera omnia. Nieuw archief voor wiskunde, 4.8 , No. 1, pp. 67-79.

EULER Leonhard

1741: Solutio problematis ad geometriam situs pertinentis. Commentarii Academiae Scientiarum Imperialis Petropolitanae 8(1736), pp. 128-140.

1743: De causa gravitatis. Miscellanea Berolinensea, 7, pp. 360-370.

1768: Lettres à une princesse d'Allemagne sur divers sujets de physique et de philosophie. St. Petersbourg: Imprimerie de l’Académie Impériale des Sciences.

1862: Opera postuma mathematica et physica. Petropoli: Eggers; Rigae: Schmidt; Lipsiae: Voss.

FELLMANN Emil A.

2007: Leonhard Euler. Basel, Boston, Berlin: Birkhäuser. ISBN 978-3-7643-7538-6. Trans. by Erika Gautschi and Walter Gautschi.

FELLMANN Emil A., IM HOF, Hans Christoph

1993: Die Euler-Ausgabe - Ein Bericht zu ihrer Geschichte und ihrem aktuellen Stand. Jahrbuch Überblicke Mathematik, pp. 185-198. 
FUSS Paul-Heinrich

(ed.) 1843: Correspondance mathématique et physique de quelques célèbres géomètres du XVIIIème siècle, précédée d'une notice sur les travaux de Léonard Euler, tant imprimés qu'inédits. Vol. 1. Saint-Pétersbourg: Imprimerie de l’Académie Impériale des Sciences.

GRIGORIAN Ašot T., YOUSCHKEVITCH Adolf P.

(ed.) 1968: Relations scientifiques russo-françaises. Leningrad: Nauka.

HAGEN Johann Georg

1896: Index operum Leonardi Euleri. Berolini: Dames.

JUŠKEVIČ Adolf P., WINTER Eduard

(ed.) 1959-1976: Die Berliner und die Petersburger Akademie der Wissenschaften im Briefwechsel Leonhard Eulers. Vol 1-3. Berlin: Akademie-Verlag.

(ed.) 1965: Leonhard Euler und Christian Goldbach. Briefwechsel 1729-1764. Berlin: Akademie-Verlag.

ЮШКЕВИЧ Адольф П., СМИРНОВ Владимир И.

(ed.) 1967: Леонард Эйлер. Переписка. Аннотированный указатель. Ленинград: Издательство наука.

КЛАДО Т. Н., КОПЕЛЕВИЧ Ю. Х., ЛУКИНА, Т. А.

(еd.) 1963: Леонард Эйлер. Письма к ученым. Москва, Ленинград: Издательство Академии наук СССР.

KLEINERT Andreas

2015: Euler, Lesage et Newton. Trois approches différentes pour résoudre le problème de la pesanteur. [In:] Leonhard Euler. Mathématicien, physicien et théoricien de la musique. Edited by Xavier Hascher and Athanase Papadopoulos. Paris: CNRS Editions. ISBN 978-2-271-08331-9, pp. 301-313.

KLEINERT Andreas, MATTMÜLLER Martin

2007: Leonhardi Euleri Opera Omnia: a centenary project. Newsletter of the European Mathematical Society, 65, pp. 25-31. Available online: http://www.ems-ph.org/journals/newsletter/pdf/2007-09-65.pdf (23.09. 2015).

LIBRI Guglielmo

1846: Review of Fuss 1843, part 2. Journal des savants, pp. 50-62.

LINNÉ PROJECT

2003-2015: The Linnaean Correspondence. Available online: http://linnaeus.c18.net/.

RUDIO Ferdinand, SCHRÖTER Karl

1907: Notizen zur schweizerischen Kulturgeschichte: 21. Der zweihundertjährige Geburtstag von Leonhard Euler; 22. Der Plan einer Gesamtausgabe von Eulers Werken. Vierteljahrsschrift der Naturforschenden Gesellschaft in Zürich, 52, pp. 537-546. 
1909: Notizen zur schweizerischen Kulturgeschichte: 26. Die Eulerausgabe (Fortsetzung). Vierteljahrsschrift der Naturforschenden Gesellschaft in Zürich, 54, pp. 463-480.

STÄCKEL Paul

1909: Entwurf einer Einteilung der Werke Leonhard Eulers. Vierteljahrsschrift der Naturforschenden Gesellschaft in Zürich, 54, pp. 1-28.

RUDIO Ferdinand

1911: Vorwort zur Gesamtausgabe der Werke von Leonhard Euler. [In:] Leonhardi Euleri opera omnia, I,1, pp. IX-XLI.

UNIVERSITÄTSBIBLIOTHEK BASEL

2015: Basler Edition der Bernoulli-Briefwechsel. Available online: http://www.ub.unibas.ch/bernoulli/index.php/Hauptseite.

\section{SUMMARY}

The edition of the works of Leonhard Euler, entitled Leonhardi Euleri opera omnia, is a monument of scholarship known to most historians of science and certainly to every historian of mathematics.

Born in Basel in 1707, Euler studied mathematics with Johann I Bernoulli at Basel University. In 1727, he followed an invitation to the St. Petersburg Academy of Sciences. In 1741, he moved to Berlin where he became director of the class of mathematics of the Prussian Academy. 25 years later, in 1766, he returned to St. Petersburg as a full member of the Russian Academy of Sciences. He held this position until his death in 1783.

During his lifetime, Euler published about 560 writings. Until 1830, nearly 200 more papers were published from the stock of unpublished manuscripts he had left behind. In 1862, another 61 papers were published under the title Opera postuma mathematica et physica.

Between 1910 and 1913, the Swedish mathematician Gustav Eneström compiled the standard inventory of Euler's writings, the Eneström Index. According to this inventory, the total number of Euler's printed publications amounts to about 850 .

In the $19^{\text {th }}$ and early $20^{\text {th }}$ century, several attempts were made to publish an edition of Euler's complete works. For financial and organizational reasons all these initiatives ended with a failure, including the project of a common publication by the Petersburg and the Berlin Academies of Sciences, launched by the Russian Academy in 1903.

In 1907, on the occasion of Euler's $200^{\text {th }}$ birthday, the Swiss Society for Natural Science started the initiative that ultimately turned out to be successful. The task of realizing the project was assigned to a permanent committee (Euler-Kommission). In a worldwide fundraising campaign and through subscriptions by the leading European academies the society collected nearly half a million Swiss francs in order to guarantee medium-term fi- 
nancing of the project. Mathematicians of international reputation spontaneously agreed to serve as editors of one or more volumes, and the first volume of the edition appeared in 1911. Until the outbreak of World War I, 12 volumes were published.

When the edition started, the total number of volumes was estimated to about 40 , and the duration of the project to approximately 12 years. Within the following years, the number of volumes was raised to 72. Euler's printed works should be arranged within the three series: I. Mathematics (29 volumes), II. Mechanics and Astronomy (31 volumes), and III. Physics and Miscellaneous (12 volumes).

During the $20^{\text {th }}$ century, the edition passed through different ups and downs, including the bankruptcy of the bank where the Euler committee had deposited its funds. In the second half of the $20^{\text {th }}$ century, it became more and more difficult to find qualified editors among mathematicians and physicists, because most of them were no longer capable of reading and commenting Latin texts. After 1960, scientists were increasingly replaced as editors by professional historians of science.

Along with the arrival of a new generation of editors, the edition began to focus on a different target group of readers. Its promoters in the early $20^{\text {th }}$ century intended to make Euler's works accessible to mathematicians, which is no longer possible with texts written in Latin, German and French. While the importance of the edition for mathematicians diminished, it became a useful tool for historians interested in science and its social and political context in the $18^{\text {th }}$ century Europe. Today, historians and, in particular, professional historians of science have taken over the place of the mathematicians both as readers and in the function of editors.

Now (in 2015), the edition of Euler's printed works is nearly finished. The two missing volumes of series II (II/26 and II/27) which include Euler's papers on perturbation theory in astronomy, will hopefully be published in 2016 and 2017.

In 1967, the Euler committee decided to enlarge the edition by a forth series that should contain Euler's correspondence (series IVA) and unpublished manuscripts (series IVB). Series IVB was postponed and the publication of series IVA started in 1975 with an inventory of approximately 3,000 letters from and to Euler that were known at that time. The descriptions of the items include indications of the libraries or archives where they are preserved and a brief summary of the content (in German).

In series IVA, Euler's correspondence is not published in a chronological order; instead any single volume will include the exchange of letters with one or more correspondents. For each volume, a „working language“ is defined for the introduction, the footnotes and the commentaries. According to the languages of the letters, the working languages are mostly French or German. For volume IVA/9 (correspondence with Martin Knutzen, mostly in Latin) the working language will be Italian. The letters are published completely, including the civilities at the beginning and at the end, which were often omitted in former editions. All letters are given in the original language; letters in Latin will additionally be translated into the working language of the volume.

An exception was made for the Goldbach correspondence (vol IVA/4), which includes many topics of interest for modern mathematics, in particular number theory. 
In order to make it easily accessible to a worldwide community of mathematicians, it was decided to choose English as the working language and to translate all the letters into English, in addition to the original text.

After volume IVA/1, four more volumes were published until 2015. Another four volumes are in preparation. The remaining letters will hopefully be published in an online edition.

Apart from a few exceptions, the editors serve as volunteers. The material basis of their work are scans or photocopies of Euler letters gathered from archives and libraries worldwide, and photographs of the letters addressed to Euler that are part of the Euler papers preserved in the Petersburg archive of the Russian Academy of Sciences.

Two Euler correspondents are of special interest for the history of science in Poland: Carl Gottlieb Ehler and Heinrich Kühn, who were both were mathematicians in Gdansk. A famous topic of their correspondence with Euler is the problem of the seven bridges of Königsberg.

The Euler correspondence is not only of interest for the history of mathematics. Volume IVA/8 (correspondence with Johann Andreas von Segner and other professors of the university of Halle) will provide new insights into everyday life in a Prussian university in the $18^{\text {th }}$ century, and a letter to be published in volume IVA/7 reveals Euler as the author of an anonymously published paper on the cause of gravitation.

\section{LEONHARDI EULERI OPERA OMNIA: WYDANIE DZIEŁ I KORESPONDENCJI LEONHARDA EULERA}

\section{Streszczenie}

W artykule przedstawiono historię i stan obecny wydań dzieł zebranych Leonharda Eulera (1707-1783). Po kilku nieudanych inicjatywach edytorskich, podjętych w XIX wieku, w 1907 roku przystąpiono do wydania drukowanych prac Eulera. Edycję podzielono na trzy serie: seria I: Matematyka (29 tomów); seria II: Mechanika i astronomia (31 tomów); seria III: Fizyka i inne prace (12 tomów). Po licznych perturbacjach, m.in. związanych z wybuchami kolejnych wojen światowych i problemami ekonomicznymi, publikacja dzieł drukowanych w łącznej liczbie 72 tomów zbliża się do końca. Brakuje tylko dwóch tomów o rachunku zaburzeń w astronomii.

Do publikacji serii IV (rękopisy i korespondencja) przystąpiono w 1967 roku. W przedsięwzięcie zaangażowały się szwajcarska i radziecka akademie nauk. Ten wspólny projekt koncentruje się na edycji korespondencji Eulera, która zawiera blisko 3000 listów, spośród których prawie 1000 napisał sam Euler. Adresatami jego listów byli m.in. słynni matematycy z XVIII wieku, tacy jak Jean le Rond d'Alembert, Alexis Clairaut i rodzina Bernoullich, ale również wiele mniej znanych osób, z którymi Euler korespondował na rozmaite tematy. Wydanie rękopisów zostało odłożone na późniejszy okres. 
Poważnym problemem było znalezienie i sfinansowanie pracy odpowiednich redaktorów, którzy byli w stanie czytać stare manuskrypty po francusku, łacinie i po niemiecku oraz byli zaznajomieni z historią, kulturą i nauką w XVIII wieku. W ciągu ostatnich 50 lat redaktorzy zebrali kopie lub skany większości zachowanych listów Eulera. Oryginalne listy adresowane do Eulera Rosyjska Akademia Nauk udostępniła przed I wojną światową grupie wydawniczej ze Szwajcarii. Jeszcze przed ich restytucją w 1947 roku, redaktorzy wykonali dobrej jakości fotograficzne kopie, które dzisiaj są istotną podstawą wydania. Na każdy z tomów listów (VIA) składa się korespondencja Eulera z jedną lub kilkoma osobami , do których były adresowane jego listy; wszystkie zostały zamieszczone w porządku chronologicznym. Do dzisiaj ukazały się cztery tomy korespondencji wraz z wykazem wszystkich znanych listów adresowanych do Eulera oraz przez niego wysyłanych. W wykazie znajdziemy krótkie podsumowanie i przydatne informacje na temat daty, języka, lokalizacji istniejących kopii i wcześniejszych publikacji. Cztery kolejne tomy są przygotowywane do druku i zostaną wydane w 2016 lub 2017 roku. Planowane jest udostępnienie $\mathrm{w}$ internetowym wydaniu pozostałych listów, których nie pomieszczono w wersji drukowanej.

Słowa kluczowe: Leonhard Euler, dzieła zebrane, korespondencja, zasady edycji 